\section{Nature}

October 2006; Volume 443 (7113) : Pages 854-858

http://dx.doi.org/10.1038/nature05227

Copyright @ 2006 Nature Publishing Group
Archimer http://www.ifremer.fr/docelec/ Archive Institutionnelle de l'Ifremer

The original publication is available at http://www.nature.com

\title{
Novel microbial communities of the Haakon Mosby mud volcano and their role as a methane sink
}

\author{
Helge Niemann ${ }^{1,2,5}$, Tina Lösekann ${ }^{1,5}$, Dirk de Beer ${ }^{1}$, Marcus Elvert ${ }^{1,6}$, Thierry Nadalig ${ }^{3,6}$, Katrin \\ Knittel $^{1}$, Rudolf Amann ${ }^{1}$, Eberhard J. Sauter ${ }^{2}$, Michael Schlüter ${ }^{2}$, Michael Klages ${ }^{2}$, Jean Paul Foucher ${ }^{3}$ \\ \& Antje Boetius ${ }^{1,2,4}$,
}

\footnotetext{
${ }^{1}$ Max Planck Institute for Marine Microbiology, 28359 Bremen, Germany

2 Alfred Wegener Institute for Polar and Marine Research, 27515 Bremerhaven, Germany

${ }^{3}$ Centre Ifremer de Brest, BP70, 29280 Plouzane, France

4 International University Bremen, 28759 Bremen, Germany

${ }^{5}$ These authors contributed equally to this work.

${ }^{6}$ Present addresses: DFG Research Center Ocean Margins, University of Bremen, 28334 Bremen, Germany (M.E.); UMR 7156 Université Louis-Pasteur/CNRS, Département Microorganismes, Génomes, Environnement, 67083 Strasbourg Cedex, France (T.N.).
}

*: Corresponding author : A. Boetius, email address : aboetius@mpi-bremen.de

\begin{abstract}
:
Mud volcanism is an important natural source of the greenhouse gas methane to hydrosphere and atmosphere ${ }^{1,2}$. Recent investigations show that the number of active submarine mud volcanoes may be much higher than anticipated (eg. 3-5), and that gas emitted from deep-sea seeps may reach the upper mixed ocean ${ }^{6-8}$. Unfortunately, global methane emission from active submarine mud volcanoes cannot be quantified because their number and gas release is unknown ${ }^{9}$. Another uncertainty is the efficiency of methane oxidizing microorganisms in methane removal. Here we investigated the methane-emitting Haakon Mosby Mud Volcano (HMMV, Barents Sea, $72^{\circ} \mathrm{N}, 1^{\circ} 44^{\prime} \mathrm{E} ; 1250 \mathrm{~m}$ water depth), to provide quantitative estimates of in situ composition, distribution and activity of methanotrophs in relation to gas emission. The HMMV hosts three key communities; aerobic methanotrophic bacteria (Methylococcales), anaerobic methanotrophic archaea (ANME-2) thriving below siboglinid tubeworms, and a novel clade of archaea (ANME-3) associated with bacterial mats. We found that upward flow of sulphate- and oxygen-free mud volcano fluids restricts the availability of these electron acceptors for methane oxidation, and hence the habitat range of methanotrophs. This mechanism limits the capacity of the microbial methane filter at active marine mud volcanoes to $<40 \%$ of the total flux.
\end{abstract}

The HMMV (Fig. 1), a circular structure of $1 \mathrm{~km}$ diameter and $<10 \mathrm{~m}$ elevation above the adjacent seafloor, has been studied since the 1990 s as a typical example of an active mud volcano ${ }^{9}$. Its formation may have coincided with a submarine landslide during the late Pleistocene, 330-200 ka before present ${ }^{10}$. Today, fluids, gas and muds rise from $2-3 \mathrm{~km}$ depth through a conduit below the $\mathrm{HMMV}^{11,10}$. The emitted gas is of a mixed microbial/thermogenic origin and consists of $>99 \% \mathrm{CH} 4$ with a $\delta^{13} \mathrm{C}$-isotope signature of $-60 \%{ }^{12,13}$. The rising fluids are depleted in sulphate, chloride and magnesium caused by subsurface clay dewatering ${ }^{11}$. Investigation of the HMMV with RV POLARSTERN and ROV VICTOR 6000 in 2003 showed extensive outcroppings 
of fresh subsurface muds associated with steep thermal gradients ${ }^{14}$, gas and fluid vents, and a large gas plume reaching the mixed upper water column above the HMMV ${ }^{12,8}$. Seafloor videography in combination with geochemical measurements provided in situ estimates of gas flux ${ }^{8}$, fluid flow ${ }^{15}$ and habitat distribution ${ }^{16}$. We focused on the three main concentric habitats above the gassy muds (Fig. 2): the centre of HMMV, which was devoid of epifauna; thiotrophic bacterial mats dominated by a Beggiatoa species; and surrounding fields of siboglinid tubeworms. Gas concentrations in sediments and bottom water were elevated in all three habitats (Tab. 1). An essential difference between the habitats are the fluid flow velocities modelled from in situ gradients of temperature, oxygen and sulphide concentrations ${ }^{15}$. The results suggest that the upward transport of oxidant-depleted mud volcano fluids hinders downward diffusion of oxygen and sulphate, and limits methanotrophic habitats in the centre and below bacterial mats to the uppermost milli- to centimetres, respectively ${ }^{15}$. We have now identified and quantified the methanotrophs populating the three habitats to assess their role in controlling methane flux at HMMV (Tab. 1; Figs. 2, 3).

The surface of the most recent mud flows in the centre of the HMMV, characterized by steep temperature gradients of $3^{\circ} \mathrm{C} \mathrm{m}^{-1}(14)$, hosted high microbial cell numbers, reaching $5.1 \pm 0.3 \times 10^{9}$ cells $\mathrm{cm}^{-3}$, of which $50( \pm 5) \%$ belonged to type I aerobic methanotrophic bacteria of the order Methylococcales and Methylophaga (Figs. 2-3, 3a3). The 16S rRNA gene sequences of the dominant Methylococcales types (HMMV-MetI and -MetII) are closely related to sequences of methanotrophic mussel symbionts (94-97\%) ${ }^{17}$ and to clone sequence Hyd24-1 (96-99\%) from gas hydrate bearing sediments of Hydrate Ridge ${ }^{18}$. High concentrations of a ${ }^{13} \mathrm{C}$-depleted $(-80 \%$ ), type I methanotroph specific fatty acid (FA; C16:108c) were found in the same samples (Fig. 3a4). As predicted by the fluid flow model for this area ${ }^{15}$, methanotroph cell numbers, lipid biomarkers and aerobic methane oxidation rates (MOx) peaked in the uppermost surface sediment and decreased $>5$-fold in the second $\mathrm{cm}$ because of limited 
oxygen penetration (Fig. 3a). Only minor amounts of methanotroph lipids $(<0.1 \mu \mathrm{g}$ g$\left.\mathrm{dw}^{-1}\right)$ and very low cell numbers $\left(\sim 10^{7}\right.$ cells $\left.\mathrm{cm}^{-3}\right)$ were found below $5 \mathrm{~cm}$ sediment depth (Fig. 3a3-3a4). ANME cells were not microscopically detectable in the centre cores using all known ANME oligonucleotide probes, and the anaerobic oxidation of methane (AOM) remained below detection.

In situ microsensor profiles of sulphide concentrations in HMMV sediments suggested that AOM occurs in older mud flows at 2-3 $\mathrm{cm}$ below the sulphide-oxidizer mats (Fig. 2-4). Accordingly, microbial biomass peaked in the top $3 \mathrm{~cm}$ (Fig. 3b3) and mainly consisted of a novel consortium of archaea and sulphate-reducing bacteria (SRB) forming dense cell aggregates (Fig. 2-4). 16S rRNA gene analyses of DNA revealed a dominant cluster of archaeal sequences forming a new phylogenetic group named ANME-3 (Supplement Fig. 1). Single sequences of this novel cluster were only sporadically detected at cold seeps ${ }^{19,20}$, which are typically dominated by other phylogenetic clades of anaerobic methanotrophs, i.e. ANME-1 and ANME-2 together with their bacterial partner, sulphate reducers (SRB) of the Desulfosarcina/Desulfococcus (DSS) branch ${ }^{21,19,20}$. We propose that members of the ANME-3 cluster are also capable of AOM, based on the coinciding AOM maximum with the sulphide production zone, the presence of high numbers of ANME-3 aggregates (20 $( \pm 0.6) \times 10^{6}$ aggregates $\mathrm{cm}^{-3}$ at $1-2 \mathrm{~cm}$ sediment depth) making up 81\% of total cell numbers, and highly elevated lipid biomarker concentrations of sn2hydroxyarchaeol, archaeol and specific penta-methyl-icosenes (Fig. 3b). Moreover, stable C-isotope signatures of the archaeal lipid biomarkers of $\delta^{13} \mathrm{C}$-values <-98\%o indicate that methane is the main carbon source of ANME-3 cells. Analyses of $16 \mathrm{~S}$ rRNA genes and lipid biomarkers showed that the bacterial partner associated with ANME-3 is different from all other ANME consortia (see supplementary information). It is closely related to Desulfobulbus spp. (DBB) and also takes up methane-derived carbon as indicated by the $\delta^{13} \mathrm{C}$-value of $-70 \%$ of its specific lipid biomarker C17:1 $\omega 6 \mathrm{c}$ 
(Fig. 3b4). As predicted by the fluid flow model, 95\% of all ANME-3/DBB aggregates were found directly below the Beggiatoa mats (Fig. 3b-3). Because of reduced fluid flow velocities, sulphate can penetrate the upper 4-6 $\mathrm{cm}$ of the sediment column (Fig. 3b2, Tab 1). Furthermore, the re-oxidation of sulphide by the sulphide oxidizer mats replenishes the sulphate pool in these sediments, further contributing to the maintenance of high activity and biomass of the AOM community in this zone.

The next major transition in HMMV habitats occurs about 300-400 m from its geographical centre, where the sulphide-oxidizer mats are replaced by dense tubeworm colonies on the hummocky periphery of the HMMV (Fig. 2-5, Tab 1). Two siboglinid tubeworm species, Oligobrachia haakonmosbiensis and Sclerolinum contortum ${ }^{13}$ populate this area with biomasses of $1-2 \mathrm{~kg}$ wet weight $\mathrm{m}^{-2}$ (estimated from sieved boxcore samples). O. haakonmosbiensis, the dominant species in the investigated area, is up to $60 \mathrm{~cm}$ long and has a diameter of $0.5 \mathrm{~mm}$. In the tubeworm fields, fluid flow rates modelled from temperature profiles $\left(0.4 \mathrm{~m} \mathrm{yr}^{-1}\right)$ were lower than those in the centre or bacterial mat area ${ }^{14}$. In agreement with the low subsurface temperature gradient in this zone (Fig. 3b1, 3c1) ${ }^{14}$, gravity cores from this area contained gas hydrate below the worm-infested sediment layers. Balancing downward diffusion and upward fluid flow, maximum sulphate penetration could reach $12 \mathrm{~cm}$. However, the measured oxygen and sulphate penetration in the tubeworm field (Fig. 2-5; 3c1-3c2; Tab 1) show that the tubeworms substantially increase the transport of electron acceptors into deeper sediment layers. Accordingly, the maximum in AOM was found between the base of the worm tubes and the hydrate layer (60-90 cm bsf), coinciding with a subsurface peak of ANME-2/DSS aggregates (5.5 × $10^{6}$ aggregates) and their specific biomarker lipids (Fig. 3c). Integrated ex situ methane consumption was higher than in other zones of HMMV (Tab. 1). Microbe-invertebrate symbioses have an advantage over free-living microbial populations because they can engineer their environment to increase access to both electron donors and acceptors by special migratory behaviour, mining and 
pumping. It remains an interesting question which factors determine the transition between Beggiatoa mats and tubeworm fields, and the temporal succession of the thioand methanotrophic communities. Visual observation of the seafloor showed that sulphide oxidizing mats and tubeworms are mutually exclusive, i.e. no worms were found within any bacterial mats. The tubeworms have a clear advantage over bacterial mats because they can reach much deeper zones of sulphide production, and may efficiently compete for sulphide and methane uptake. Probably tubeworm larvae cannot settle on Beggiatoa mats due to the high fluid flow and high AOM-based sulphide concentration present in this habitat.

In conclusion, we found that methane oxidation was the main energy source for microbial biomass in all different habitats of HMMV. Populations of aerobic or anaerobic methanotrophs comprised between $50-80 \%$ of the total microbial community (centre and Beggiatoa mat habitats). At their maxima in abundance and activity (Fig. 3), both communities show relatively low ${ }^{22}$ cell-specific rates of methane oxidation, of $<0.1$ fmol $\mathrm{CH}_{4}$ per cell and day under atmospheric pressure and an ambient temperature of $1^{\circ} \mathrm{C}$. The total integrated activity and biomass was lower for the aerobic methanotrophs than for the AOM communities, as they were limited to the surface of the centre muds by high fluid flow (Tab. 1 and supplementary information). ANME-3 and ANME-2 consortia both dominate areas with lower flow and profit from the association with other organisms re-oxidizing sulphide to sulphate. Total methane consumption in the centre, Beggiatoa and tubeworm habitats was up to $0.4,1.8$ and $2.9 \times 10^{6} \mathrm{~mol} \mathrm{yr}^{-1}$, respectively (sum $5.1 \times 10^{6} \mathrm{~mol} \mathrm{yr}^{-1}$ ). In 2003, methane emission to the hydrosphere from HMMV reached at least 8 to $35 \times 10^{6} \mathrm{~mol} \mathrm{yr}^{-1}$ (8) resulting in a total methane flux of 13 to $40 \times 10^{6} \mathrm{~mol} \mathrm{yr}^{-1}$. Aerobic oxidation of methane played a minor role (1-3\%) compared to anaerobic oxidation, which removed up to $37 \%$ of the total methane flux. Hence, the efficiency of microbial methane removal is substantially lower than in other methane-fuelled systems ${ }^{23-25}$. These data confirm that fluid advection is a main habitat- 
structuring factor at cold seep ecosystems, by regulating availability of electron acceptors and hence distribution and activity of methanotrophs. It is generally assumed that with increasing upward flow velocities, more dissolved methane is transported to the surface, fuelling increasingly active seep communities (e.g. ${ }^{26}$ ). However, geofluids produced from compaction processes and dewatering are electron-acceptor depleted. High flows of methane-laden fluids introduce a negative switch in the fluid flow/methanotroph activity relationship. Furthermore, if such fluids transport heat from below, they may even suppress formation of hydrate, which represent an important although dynamic - sink for methane on earth ${ }^{27}$. Consequently, as in the case of the HMMV, methane rising with warm, oxidant-depleted fluids may accumulate in muds and escape as free gas to the hydrosphere. Here we have shown that the efficiency of the microbial filter against methane already decreases considerably at fluid flow rates $>0.4$ $\mathrm{m} \mathrm{yr}^{-1}$, causing increased efflux of methane to the hydrosphere and probably even atmosphere ${ }^{8}$. Velocities of decimetres to metres $\mathrm{yr}^{-1}$ are within the average range of fluid flow measured at cold seeps ${ }^{28,29}$, hence the described inhibition of microbial methane consumption may be widespread at seeps. Further quantitative in situ measurements of fluid flow and microbial methane consumption are necessary to constrain the relevance and control of methane emission from submarine mud volcanoes and other fluid-flow driven geo-bio-systems.

\section{Methods}

\section{Sampling}

Our studies took place during two cruises with R/V “L'Atalante” (2001) and R/V "Polarstern" (2003) both equipped with ROV "VICTOR 6000. Sediments were collected with ROV pushcores and gravity cores for on board (“ex situ”) measurements. Sediment cores as well as in situ microsensor profiles were obtained along a radial 
transect from the centre to the east of the mud volcano (Fig. 1b). Bottom water was sampled with a bottom water sampler and methane concentrations were determined by gas chromatography ${ }^{8}$. A detailed description of the methods described here is provided in the online supplements.

\section{Sulphate reduction and methane oxidation rates}

Microbial rates of aerobic and anaerobic methane oxidation (MOx and AOM, respectively) and sulphate reduction (SR) in sediments were determined ex situ using ${ }^{14} \mathrm{CH}_{4}$ and ${ }^{35} \mathrm{SO}_{4}{ }^{2-}$ tracers ${ }^{25,22}$.

\section{Lipid analysis}

Lipid biomarker from frozen sediment samples and tubeworm tissue were extracted, separated and derivatised as described previously ${ }^{30,22}$. Single lipid compounds were analysed by gas chromatography, mass spectrometry and isotope ratio mass spectrometry for quantity, identity and stable carbon isotope ratio, respectively ${ }^{30}$.

\section{Fluorescence in situ hybridisation (FISH)}

Cells of Methylococcales as well as ANME-3/DBB and ANME-2/DSS aggregates were quantified by FISH with monolabeled oligonucleotide probes according to previously described methods ${ }^{20}$. 


\section{Sulphate and chloride concentrations}

Sulphate concentrations were determined by HPLC analysis from the supernatant of 5 $\mathrm{ml}$ sediment fixed with $25 \mathrm{ml}$ zinc acetate solution ${ }^{25}$. Chloride concentrations were determined from pressure filtered pore water by ion chromatography.

\section{Microsensor measurements}

Microsensors (20 $\mu \mathrm{m}$ tip diameter) for oxygen, $\mathrm{H}_{2} \mathrm{~S}$ and $\mathrm{pH}$ were manufactured and used as described previously ${ }^{15}$. Profiles were recorded in situ with a spatial resolution of $0.025 \mathrm{~cm}$ by deploying a profiler unit (equipped with the sensors) with the ROV or a free falling lander system. A detailed description of in situ data and the geochemical models applied here is provided elsewhere ${ }^{15}$.

Supplementary Information accompanies the paper on www.nature.com/nature.

1

2 A. V. Milkov, R. Sassen, T. V. Apanasovich et al. Global gas flux from mud volcanoes: A significant source of fossil methane in the atmosphere and the ocean. Geophysical Research Letters 30 (2) (2003).

3 G. Bohrmann, M. Ivanov, J. P. Foucher et al. Mud volcanoes and gas hydrates in the Black Sea: new data from Dvurechenskii and Odessa mud volcanoes. GeoMarine Letters 23 (3-4), 239 (2003).

4 L. M. Pinheiro, M. K. Ivanov, A. Sautkin et al. Mud volcanism in the Gulf of Cadiz: results from the TTR-10 cruise. Marine Geology 195 (1-4), 131 (2003).

$5 \quad$ L. Loncke and J. Mascle. Mud volcanoes, gas chimneys, pockmarks and mounds in the Nile deep-sea fan (Eastern Mediterranean): geophysical evidences. Marine and Petroleum Geology 21 (6), 669 (2004).

$6 \quad$ I. R. MacDonald, I. Leifer, R. Sassen et al. Transfer of hydrocarbons from natural seeps to the water column and atmosphere. Geofluids 2 (2), 95 (2002).

7 G. Rehder, P. W. Brewer, E. T. Peltzer et al. Enhanced lifetime of methane bubble streams within the deep ocean. Geophysical Research Letters 29 (15) (2002). 
E. J. Sauter, S. I. Muyakshin, J. L. Charlou et al. Methane discharge from a deep-sea submarine mud volcano into the upper water column by gas hydratecoated methane bubbles. Earth and Planetary Science Letters 243 (3-4), 354 (2006). P.R. Vogt, A. Cherkashev, G. D. Ginsburg et al. Haakon Mosby mud volcano: A warm methane seep with seafloor hydrates and chemosynthesis-based Ecosystem in late Quantemary Slide Valley, Bear Island Fan, Barents Sea passive margin. EOS Transactions of the American Geophysical Union Supplement 78 (17), 187 (1997). P. R. Vogt, J. Gardner, and K. Crane. The Norwegian-Barents-Svalbard (NBS) continental margin: Introducing a natural laboratory of mass wasting, hydrates, and ascent of sediment, pore water, and methane. Geo-Marine Letters 19 (1-2), 2 (1999). G. D. Ginsburg, A. V. Milkov, V. A. Soloviev et al. Gas hydrate accumulation at the Hakon Mosby Mud Volcano. Geo-Marine Letters 19 (1-2), 57 (1999). E. Damm and G. Budéus. Fate of vent-derived methane in seawater above the Hakon Mosby mud volcano (Norwegian Sea). Mar Chem 82 (1-2), 1 (2003). A. V. Milkov, P. R. Vogt, K. Crane et al. Geological, geochemical, and microbial processes at the hydrate-bearing Hakon Mosby mud volcano: a review. Chemical Geology 205 (3-4), 347 (2004). N. Kaul, J. P. Foucher, and M. Heesemann. Estimating mud expulsion rates from temperature measurements on Hakon Mosby Mud Volcano, SW Barents Sea. Marine Geology 229 (1-2), 1 (2006). D. de Beer, E. Sauter, H. Niemann et al. In situ fluxes and zonation of microbial activity in surface sediments of the Hakon Mosby Mud Volcano. Limnol Oceanogr 51 (3), 1315 (2006). K. Jerosch, M. Schlüter, J. P. Foucher et al. Spatial distribution of mud flows, chemoautotrophic communities, and biogeochemical habitats at Håkon Mosby Mud Volcano. Marine Geology (submitted). D. L. Distel, H. K. W. Lee, and C. M. Cavanaugh. Intracellular Coexistence of Methanotrophic and Thioautotrophic Bacteria in a Hydrothermal Vent Mussel. Proc Natl Acad Sci U S A 92 (21), 9598 (1995). K. Knittel, A. Boetius, A. Lemke et al. Activity, distribution, and diversity of sulfate reducers and other bacteria in sediments above gas hydrate (Cascadia margin, Oregon). Geomicrobiol J 20 (4), 269 (2003). V. J. Orphan, K. U. Hinrichs, W. Ussler et al. Comparative analysis of methaneoxidizing archaea and sulfate- reducing bacteria in anoxic marine sediments. Appl Environ Microbiol 67 (4), 1922 (2001). K. Knittel, T. Lösekann, A. Boetius et al. Diversity and distribution of methanotrophic archaea at cold seeps. Appl Environ Microbiol 71 (1), 467 (2005). A. Boetius, K. Ravenschlag, C. Schubert et al. A marine microbial consortium apparently mediating anaerobic oxidation of methane. Nature 407, 623 (2000). H. Niemann, M. Elvert, M. Hovland et al. Methane emission and consumption at a North Sea gas seep (Tommeliten area). Biogeosciences 2, 335 (2005).

K. -U. Hinrichs and A. Boetius, in Ocean Margin Systems, edited by G. Wefer, D. Billett, and D. Hebbeln (Springer-Verlag, Berlin, Berlin, 2002), pp. 457. 
W. S. Reeburgh, in Vol. 4 Treatise on Geochemistry, edited by R. F. Keeling (Elsevier-Pergamon, Oxford, 2003), pp. 65.

25 T. Treude, A. Boetius, K. Knittel et al. Anaerobic oxidation of methane above gas hydrates at Hydrate Ridge, NE Pacific Ocean. Marine Ecology-Progress Series 264, 1 (2003). M. Sibuet and K. Olu. Biogeography, biodiversity and fluid dependence of deepsea cold-seep communities at active and passive margins. Deep-Sea Research Part II-Topical Studies in Oceanography 45 (1-3), 517 (1998). A. G. Judd, M. Hovland, L. I. Dimitrov et al. The geological methane budget at Continental Margins and its influence on climate change. Geofluids 2 (2), 109 (2002). and biogeochemical turnover in gas hydrate-bearing sediments at Hydrate Ridge, Cascadia Margin: Numerical modeling and mass balances. Geochimica Et Cosmochimica Acta 67 (18), 3403 (2003). pulsing and seismic tremor in the Costa Rica subduction zone. Earth and Planetary Science Letters 238 (1-2), 189 (2005). fatty acids as chemotaxonomic markers for sulfate-reducing bacteria involved in anaerobic oxidation of methane. Geomicrobiol J 20 (4), 403 (2003).

Acknowledgements The expeditions “AWI” on R/V “L’Atalante” in 2001 and “ARK XIX3b” on R/V

"Polarstern” in 2003 both with ROV VICTOR 6000 were jointly planned, co-ordinated and performed by the Alfred Wegener Institute for Polar and Marine Research in Bremerhaven, Germany, and by the French Research Institute for Exploitation of the Sea (IFREMER) in Brest, France. We thank the captain and crew, the team of the ROV "Victor 6000" as well as the shipboard scientific community of the R/V "Polarstern" and "L’Atalante” for their help at sea. We thank L. Baumann, V. Beier, I. Busse, F. Heinrich, G. Eickert,A. Nordhausen, J Rogenhagen, R. Usbeck for technical assistance, C Edy for help with georeferencing, U. Witte for providing the benthic lander technology, and Samantha Joye and 4 anonymous reviewers for their comments on the manuscript. This is publication no. GEOTECH-235 of the R\&D-Programme GEOTECHNOLOGIEN, Project MUMM, funded by the German Ministry of Education and Research (BMBF) and German Research Foundation (DFG), Grant 03G0554A, 03G0608A.

Competing Interests statement The authors declare no competing financial interests. 
Author Contributions statement H.N. and T.L. contributed equally to this work. T.L., T.N., K.K. and R.A. carried out the 16S-based analyses and microscopy, H.N. and M.E. the lipid biomarker work, A.B. and H.N. the rate measurements, D.B., E.S. and M.S. the microsensor and geochemical measurements, M.K., M.S., A.B. and J.P.F. the geo- and videographical survey and experimental strategy. A.B., H.N. and D.B. wrote the manuscript text, and H.N., T.L. and K.K. the supplements. All authors discussed the results and commented on the manuscript.

The nucleotide sequence data have been deposited in the EMBL, GenBank and DDBJ nucleotide sequence database under accession numbers AJ704650-AJ704653, AJ704631, AM287206-

AM287207.

Reprints and permissions information is available at npg.nature.com/reprintsandpermissions.

Correspondence should be addressed to Antje Boetius (aboetius@mpi-bremen.de). 
Figure 1. The Haakon Mosby Mud Volcano. a) Sediment echosounder image (PARASOUND) of a $1.8 \mathrm{~km}$ long profile crossing the mud volcano from south to north (pink line in panel b, $14^{\circ} 43,8 \mathrm{E}$ ). High gas content in the centre sediments considerably decreases signal penetration. The stacks of sedimentary layers of the northern and southern rims may correspond to former mudflows. Black and white bars represent $100 \mathrm{~m}$ horizontal distances. The y-axis (height) is 24 -fold exaggerated. b) High-resolution bathymetric map of the HMMV showing sampling stations (abbreviations in supplementary info). The IFREMER software CARAIBES was used to process the microbathymetry data acquired by the multibeam echosounder (Reson SeaBat 8125 and EM2000, georeferenced by Posidonia USBL positioning) mounted on ROV VICTOR.

Figure 2. A schematic diagram of the different microbial habitats at HMMV (vertical height is exaggerated 50-fold). (1) Subsurface muds rising from a deep reservoir; (2) Gas and fluid release in the northern centre. The squares (3 to 6) show images of the seafloor (top panel), idealized concentration gradients of oxygen and sulphide (left panel) and micrographs of the dominating microbial organisms (right panel; FISH probe specifications are provided in the online supplements). (3) Central sediments colonized by aerobic methanotrophic bacteria (type I methanotrophs). (4) Beggiatoa mats covering sediments dominated by an ANME-3 (red) / DBB (green) pupolation. (5) Colonies of siboglinid tubeworms harbouring symbiotic bacteria (shown in pink; host nuclei shown in blue). (6) Reference station (Micrograph: DAPI staining).

Figure 3. Vertical profiles of oxygen, sulphide and temperature (a1-c1); sulphate, ex situ methane and sulphate turnover (a2-c2), bacteria and 
aggregate counts (a3-c3) and selected lipid biomarker (a4-c4) from the centre (a), Beggiatoa-covered sediments (b) and the tubeworm field (c). Oxygen, sulphide and temperature were measured in situ with microsensors mounted on a deep-sea profiling unit. AOM, SR, sulphate, cell and aggregate counts as well as lipid biomarker contents were determined using ROV pushcorer samples from the same sites.

Table 1. Gas consumption and emission at HMMV. Total gas emission in 2003 was 8-34 $\times 10^{6} \mathrm{~mol} \mathrm{CH}_{4} \mathrm{yr}^{-1}$ based on in situ measurements at 3 active vents of $\mathrm{HMMV}^{8}$. Maximal relative methane consumption by microbial communities was estimated from microbial methane consumption* divided by the total flux. 

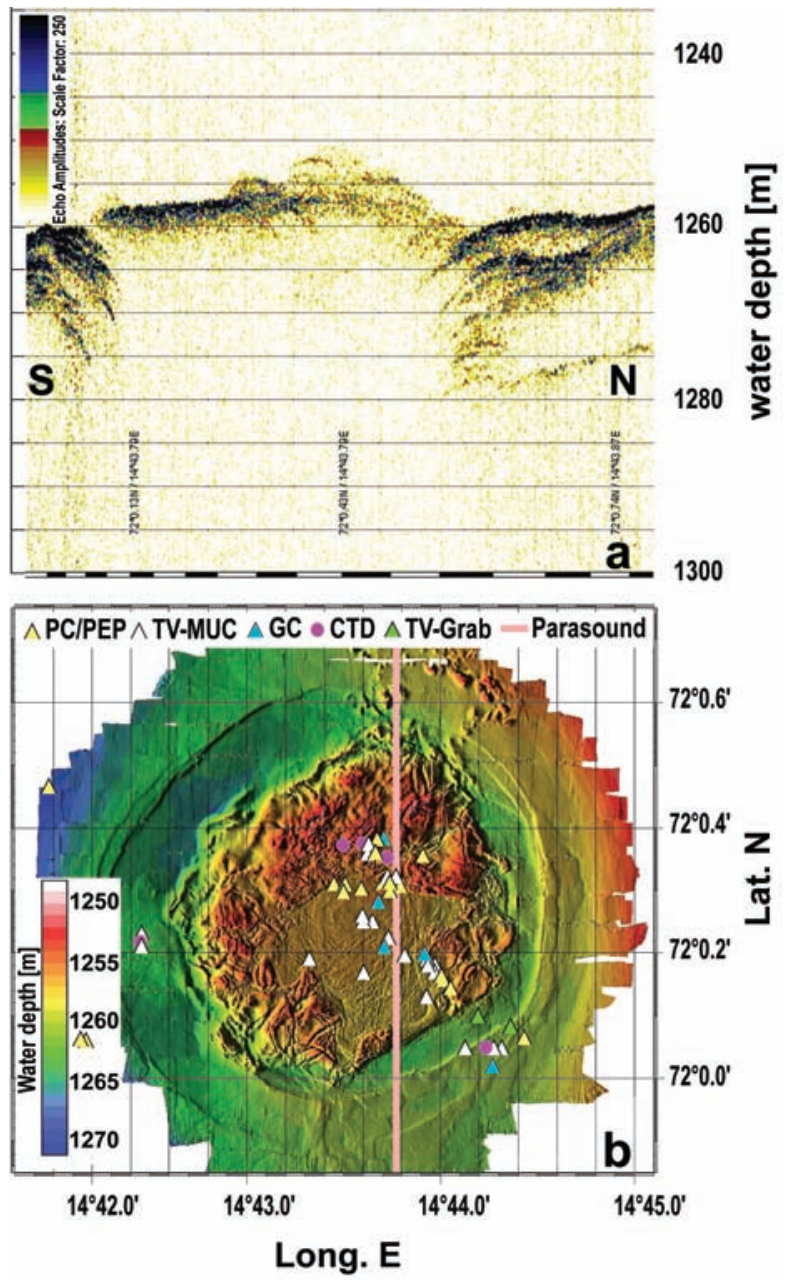

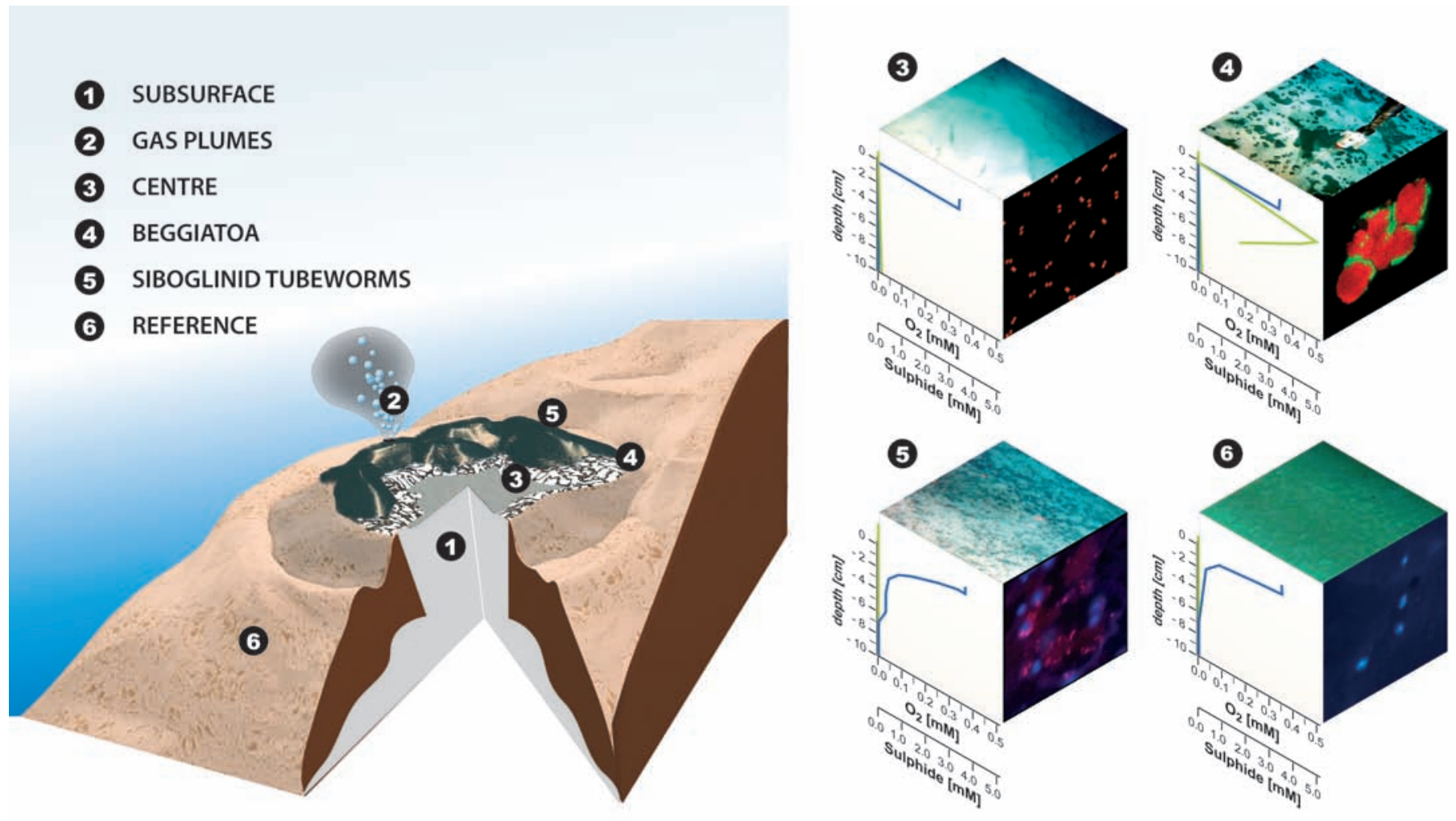


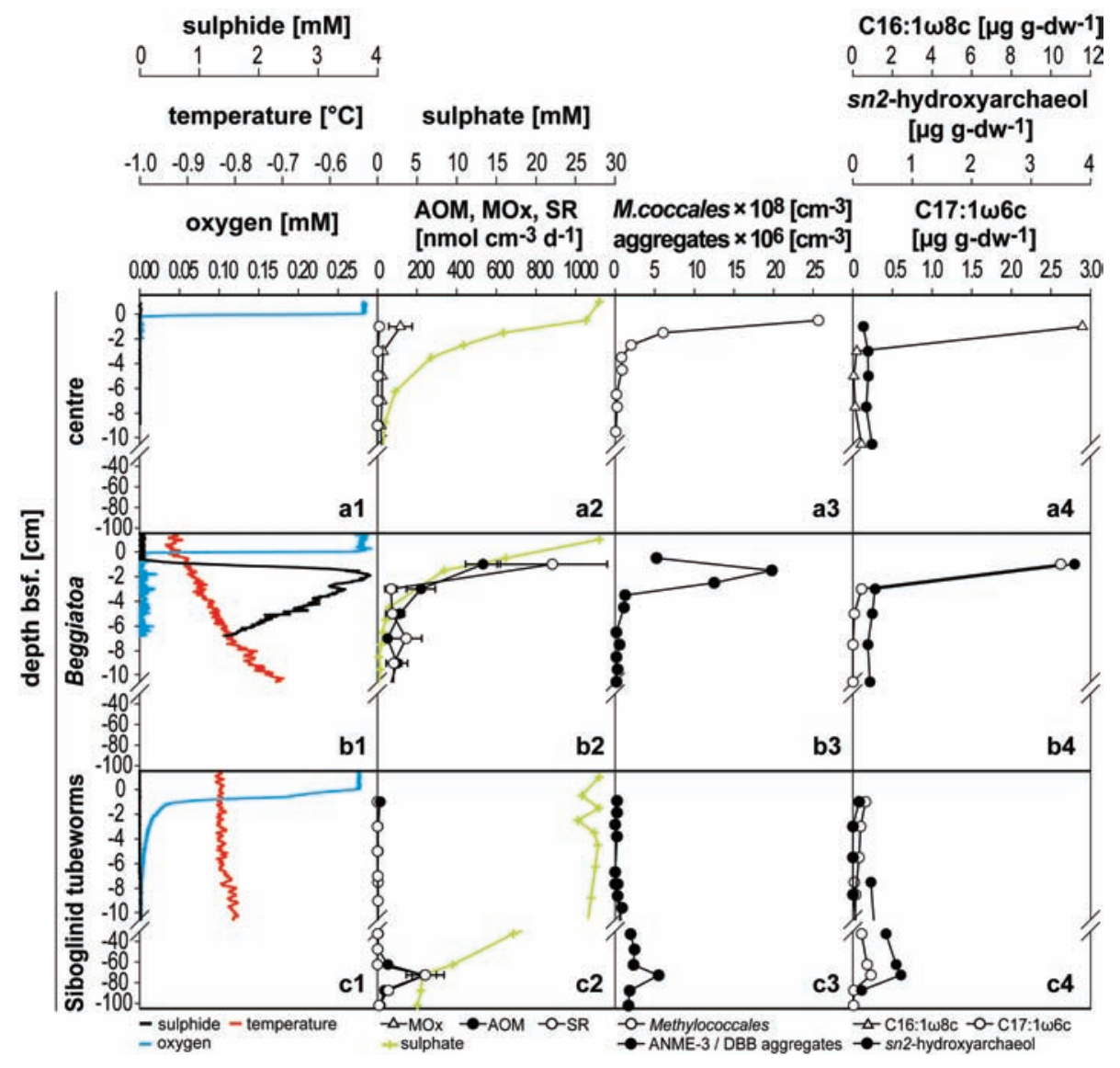




\begin{tabular}{|c|c|c|c|c|}
\hline & Centre & $\begin{array}{l}\text { Sulphide } \\
\text { oxidizer mats }\end{array}$ & $\begin{array}{l}\text { Siboglinid } \\
\text { tubeworm fields }\end{array}$ & Reference \\
\hline $\begin{array}{l}\text { area }\left[\mathrm{km}^{2}\right] \\
(\text { total }=0.74)^{16}\end{array}$ & 0.11 & 0.22 & 0.41 & \\
\hline $\begin{array}{l}\text { methane conc. }[\mu \mathrm{M}] \\
(20 \mathrm{~cm} \text { above seafloor, } \mathrm{n}=3)\end{array}$ & $5.7( \pm 1.6)$ & $0.3( \pm 0.1)$ & $0.7( \pm 0.7)$ & $0.02( \pm 0.01)$ \\
\hline $\begin{array}{l}\text { fluid flow [m yr }{ }^{-1} \text { ] } \\
\text { (based on temp. gradients) }^{14,15}\end{array}$ & $1.3-5.3$ & $0.6-1$ & 0.4 & n.a. \\
\hline $\begin{array}{l}\text { fluid flow [m yr }{ }^{-1} \text { ] } \\
\text { (based on chem. gradients) }^{15}\end{array}$ & $3-6$ & $0.3-0.6$ & n.a. & 0 \\
\hline $\begin{array}{l}\text { penetration depth [cm] } \\
\text { oxygen (in situ) }^{15}\end{array}$ & $0.1-0.3$ & $0.1-0.2$ & $3-10$ & 5 \\
\hline $\begin{array}{l}\text { penetration depth [cm] } \\
\text { sulphate (ex situ) })^{15}\end{array}$ & 2 & $4-6$ & 100 & $\begin{array}{l}>15 \\
\text { deeper data n.a. }\end{array}$ \\
\hline methanotrophs & $\begin{array}{l}\text { Methylococcales } \\
\text { Methylophaga }\end{array}$ & ANME-3/DBB & $\begin{array}{l}\text { ANME-2/DSS } \\
\text { ANME-3/DBB } \\
\text { (poss. tubew. symb.) }\end{array}$ & n.a. \\
\hline $\begin{array}{l}\text { methanotrophic } \\
\text { biomass [mol } \mathrm{C} \mathrm{m}^{-2} \text { ] }\end{array}$ & 0.04 & 0.6 & $\begin{array}{l}0.4 \\
\text { (80; tubeworm biomass) }\end{array}$ & n.a. \\
\hline ex situ MOx $\left[\mathrm{mol} \mathrm{m}^{-2} \mathrm{yr}^{-1}\right]$ & $0.9( \pm 0.4)$ & n.a. & $0.2( \pm 0.03)$ & $0.02( \pm 0.01)$ \\
\hline ex situ AOM [mol m$\left.{ }^{-2} \mathrm{yr}^{-1}\right]$ & 0 & $4.5( \pm 1.5)$ & $7.1( \pm 2.0)^{*}$ & $0.1( \pm 0.05)$ \\
\hline $\begin{array}{l}\text { in situ oxygen consumption } \\
{\left[\mathrm{mol} \mathrm{m}^{-2} \mathrm{yr}^{-1}\right]^{15}}\end{array}$ & $3.8^{*}$ & 4.1 & $\begin{array}{l}0.6 \text { (without tubeworm } \\
\text { respiration) }\end{array}$ & 0.3 \\
\hline $\begin{array}{l}\text { in situ sulphide production } \\
{\left[\mathrm{mol} \mathrm{m}^{-2} \mathrm{yr}^{-1}\right]^{15}}\end{array}$ & 0 & $8.2^{*}$ & n.a. & 0 \\
\hline $\begin{array}{l}\text { areal methane consumption } \\
{\left[10^{6} \mathrm{~mol} \mathrm{yr}^{-1}\right]}\end{array}$ & 0.4 & 1.8 & 2.9 & \\
\hline $\begin{array}{l}\text { rel. methane conumption } \\
(\% \text { of total flux, } \\
\left.13-4010^{6} \mathrm{~mol} \mathrm{yr}^{-1}\right)\end{array}$ & $1-3$ & $5-14$ & $7-23$ & \\
\hline
\end{tabular}

\footnotetext{
* values used for calculations of areal and relative methane consumption
} 


\section{Supplementary Information}

\section{Microbial methane consumption at HMMV}

Estimates of total methane flux in the ocean floor range from ca $5 \times 10^{12} \mathrm{~mol} \mathrm{yr}^{-1}$ (1) to $30 \times 10^{12} \mathrm{~mol} \mathrm{yr}^{-1}$ (assuming a 50\% contribution of shelf seas ${ }^{2}$ ). Obviously, budgeting of marine methane sources and sinks is still problematic, largely because the leakage of methane from gas hydrates and other major hydrocarbon reservoirs is not known, and the efficiency of the microbial barrier at methane seeps has not been constrained. It was estimated that the anaerobic oxidation of methane (AOM) mediated by methanotrophic archaea (ANME) consumes $90 \%$ of the methane flux from the seafloor ${ }^{3,1}$, whereas the role of aerobic methanotrophic bacteria is minor due to limited oxygen penetration. Here, we have studied an active mud volcano, to obtain a quantitative insight into the distribution and functioning of methanotrophic communities and their role as a methane sink. Only very few other investigations of the microbial ecology and biogeochemistry of active submarine mud volcanoes are available, $\mathrm{n}^{4-7}$, none of which include such a quantitative approach.

Tab. 1 summarizes the biogeochemical characteristics of the three habitats in comparison to the reference site outside of the HMMV (Fig. 2-6). The methane inventory in the bottom waters above the different habitats shows substantially higher methane concentrations above the centre, as a consequence of the reduced filtering capacity of the aerobic methanotrophs inhabiting only the thin surface horizon of the fresh muds. The $\mathrm{O}_{2}$ influx to this central area was $3.8 \mathrm{~mol} \mathrm{~m}^{-2} \mathrm{yr}^{-1}$ as determined by in

situ microsensor profiling ${ }^{8}$, equivalent to a consumption of up to $1.9 \mathrm{~mol} \mathrm{CH}_{4} \mathrm{~m}^{-2} \mathrm{yr}^{-1}$ (molar MOx stoichiometry $1 \mathrm{CH}_{4}: 2 \mathrm{O}_{2}$ ). In comparison, methane consumption below 
sulphide oxidizer mats calculated from in situ sulphide production was $8.2 \mathrm{~mol} \mathrm{~m}^{-2} \mathrm{yr}^{-1}$ (molar AOM stoichiometry $1 \mathrm{CH}_{4}: 1 \mathrm{H}_{2} \mathrm{~S}$ ), i.e. 5 times higher than average aerobic methane oxidation rates in the centre. Integrated ex situ MOx and AOM rates confirmed this trend, with $0.9 \mathrm{~mol} \mathrm{CH}_{4} \mathrm{~m}^{-2} \mathrm{yr}^{-1}$ in the centre compared to $4.5 \mathrm{~mol} \mathrm{CH}_{4} \mathrm{~m}^{-2} \mathrm{yr}^{-1}$ in the sulfide-oxidizer mats (Tab. 1). Ex situ rates were 2-fold lower than the rates calculated from in situ $\mathrm{H}_{2} \mathrm{~S}$ production and $\mathrm{O}_{2}$ consumption, probably due to degassing of methane after retrieval and incubation at atmospheric pressure.

\section{S rRNA gene analyses}

For comparative sequence analysis, a total of 67 clones carrying archaeal 16S rRNA gene sequences were obtained from HMMV near surface sediments covered with Beggiatoa mats. All sequences grouped and formed a new cluster within the order Methanosarcinales, termed ANME-3. This cluster has a distinct phylogenetic position and includes sequences from other methane seeps: the Eel River Basin ${ }^{9}$, Hydrate Ridge $^{10}$, and Eastern Mediterranean Mud Volcanoes (Heijs et al., database release). All yet known ANME-3 16S rRNA gene sequences are highly similar (95-100\%) and targeted by probe ANME3-1249 as indicated by the brackets in Fig. S-1. Closest relatives were obtained from Monterey Canyon seep sediments ${ }^{11}$ (95-98\%), an AOM bioreactor with Monterey Canyon seep sediments ${ }^{12}$ (94-97\%), and a carbonate chimney of the Lost City hydrothermal vent field ${ }^{13}$ (93-94\%). Intriguingly, ANME-3 16S rRNA gene sequences were more closely related to cultivated methanogens (Methanococcoides spp., and Methanolobus spp., 95-96\%) than any other ANME group. 
Interestingly, ANME-3 form dense aggregates with a bacterial partner (Fig. 2-4), just as their sister groups ANME-1 and $-2^{14,9,15,10}$, and a novel nitrite-dependent AOM cluster $^{16}$. The sulphate-reducing bacteria associated with ANME-3 form a new cluster of uncultivated bacteria within the Deltaproteobacteria closely affiliated with Desulfobulbus spp. (DBB) (Fig. S-2). In contrast, the bacterial partners of ANME-1 and ANME-2 belong to the Desulfosarcina/Desulfococcus clade (DSS) ${ }^{17}$. The ANME-3 associated DBB cluster has a distinct phylogenetic position and includes sequences from two other methane seeps: the Guaymas Basin and a Mediterranean Mud Volcano but also sequences from other aquatic sediments, and from electrochemical enrichments.

\section{Lipid biomarker signatures of the ANME-3 consortium}

The sediments below Beggiatoa mats of HMMV are the first habitat where ANME-3 populations have been found to dominate microbial biomass. Hence, we investigated the specific lipid biomarker fingerprint of ANME-3 in comparison to ANME-1 and -2. The archaeal lipids at this site were dominated by the glycerol diethers sn2-hydroxyarchaeol, archaeol and irregular isoprenoidal pentamethylicosenes (PMI) with four and five double bounds, all strongly depleted in ${ }^{13} \mathrm{C}\left(\delta^{13} \mathrm{C}<-98 \%\right.$ vs. Pee Dee Belemnite). Neither PMIs with higher degrees of saturation, nor crocetane were detected, all of which are characteristic for ANME-1 and ANME-2 communities ${ }^{18,14,19-21}$. Hence, a lipid signature with dominant amounts of sn2-hydroxyarchaeol relative to archaeol, the presence of PMI's with five and four double bonds and the absence of other PMI's and crocetane is indicative for ANME-3.

16S rRNA gene analysis in combination with FISH shows that a relative of DBB

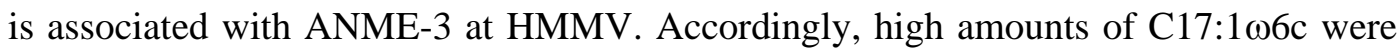


found, which was previously assigned as specific lipid biomarker to $\mathrm{DBB}^{22,23}$. This biomarker was also among the isotopically most depleted bacterial fatty acids retrieved from this site $\left(\delta^{13} \mathrm{C}:-70 \%\right)$. In contrast, ANME-1 and ANME-2 are generally associated with sulphate-reducing bacteria of the DSS group ${ }^{14,24,17}$. DSS are characterised by

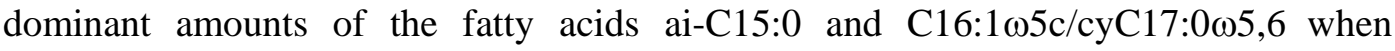
associated to ANME-1 or ANME-2, respectively ${ }^{25,19,20}$.

\section{Supplementary method information}

\section{Sampling}

Sampling stations of POLARSTERN expedition ARK XIX/3b with ROV VICTOR 6000 to HMMV are shown in Fig. 1b. Sediments were retrieved with ROV push cores (PC), TV guided multiple corer cores (TV-MUC), gravity corer cores (GC) and a TV guided grab sampler (TV-Grab). Water samples were obtained just above the sea floor with ROV PEP bottles (PEP) and from the water column with a CTD rosette (CTD) (data not shown here).

\section{Sulphate reduction and methane oxidation rates}

Microbial rates of aerobic and anaerobic methane oxidation (MOx and AOM, respectively) and sulphate reduction (SR) were determined ex situ from sediment incubations with ${ }^{14} \mathrm{CH}_{4}$ and ${ }^{35} \mathrm{SO}_{4}{ }^{2-}$ tracers ${ }^{26,21}$. Sediments from push cores were incubated using the whole core injection technique ${ }^{26}$, whereas sediment subsamples 
from gravity cores were incubated in butyl rubber sealed glass tubes $(6 \mathrm{ml})^{21}$. The ex situ cores contained ca $1.4 \mathrm{mM} \mathrm{CH}_{4}$ during incubation. Cores and glass tubes were incubated for $24 \mathrm{~h}$ at in situ temperature in the dark before the SR and AOM (MOx) reactions were stopped with $20 \% \mathrm{Zn}$-acetate or $2.5 \% \mathrm{NaOH}$ solution ${ }^{26}$, respectively. MOx and AOM were distinguished according to the presence or absence of oxygen and SR during the tracer incubations. MOx, AOM and SR rate measurements on 3-6 replicate cores per area showed a standard error of 25 to 55\% of the average value.

\section{Lipid analysis}

Lipid extracts were separated and derivatised into fatty acid methyl esters (FAMES), alcohol trimethylsilyl ethers and hydrocarbons according to previously described methods ${ }^{25,21}$ before injection into a HP 5890 Series II gas chromatograph equipped with a with a $50 \mathrm{~m}$ HP5 fused silica capillary column (0.32 mm i.d., $0.17 \mu \mathrm{m}$ film thickness) and a flame ionisation detector. Chromatographic conditions were as described previously $^{25}$ with slight modifications of the temperature gradient for the analysis of alcohol trimethylsilyl ethers and hydrocarbons. Column temperature was programmed from 60 to $150{ }^{\circ} \mathrm{C}$ at a rate of $10^{\circ} \mathrm{C} \min ^{-1}$ and then at a rate of $4{ }^{\circ} \mathrm{C} \min ^{-1}$ to $310{ }^{\circ} \mathrm{C}(45$ min isothermal). Compounds were identified on a Finnigan Trace MS. Stable carbon isotope composition of single compounds were determined using a HP 6890 Series gas chromatograph interfaced via a Combustion Interface III to a Finnigan Delta Plus isotope ratio mass spectrometer. Reported $\delta^{13} \mathrm{C}$-values (in per mil deviation from Pee Dee Belemnite, \%o) were corrected for the introduction of additional carbon atoms during derivatisation. $\delta^{13} \mathrm{C}$-values have an analytical error of $\pm 1 \%$. 


\section{Fluorescence in situ hybridisation}

Novel monolabeled oligonucleotide probes used in this study were MetI-444 (CCTGCCTGTTTTCCTCCC) and MetII-844 (GCTCCACCACTAAGACCT) for HMMV type I methanotrophs, MPH-732 (GTAATGGCCCAGTGAGTC) for Methylophaga related species, and ANME3-1249 (TCGGAGTAGGGACCCATT) for ANME-3 archaea. For Desulfobulbus spp. we used probe 660 (25) and DBB305 (AGTGCCAGTGTGACGGAT). Endosymbionts in O. haakonmosbiensis (Fig. 2-5) were stained with probes EUB338 I-III. Host cells were stained by DAPI.

\section{Sulphate and chloride concentrations}

Pore water for sulphate concentration measurements was extracted by centrifugation of $5 \mathrm{ml}$ sediment fixed in corning vials $(50 \mathrm{ml})$ with zinc acetate solution $(20 \%, \mathrm{w} / \mathrm{v})^{26}$. An aliquot of the supernatant was injected into a Waters HPLC system (Waters 512 HPLC pump, I.C.-Pak anion-column, Waters WAT007355 4.6 x 50 mm, Waters 730 conductivity detector). Isophtalic acid (1mM) was used as a solvent at a constant flow rate of $1 \mathrm{ml} \mathrm{min}{ }^{-1}$. Chloride concentrations were determined from pore water extracted by pressure filtration ( 5 bars) through Teflon squeezers provided with $0.2 \mu$ m cellulose acetate filters. Pore water aliquots were analysed using a Metrohm ${ }^{\mathrm{TM}} 761$ Compact IC with chemical suppression, equipped with a $250 \times 4 \mathrm{~mm}$ ultra high capacity column (Metrosep $^{\mathrm{TM}}$ A Supp 5) and a and conductivity detector. A carbonate buffer solvent (3.2 $\mathrm{mM} \mathrm{Na} \mathrm{CO}_{3} / 1 \mathrm{mM} \mathrm{NaHCO}$ ) was used at a flow rate of $0.7 \mathrm{ml} \mathrm{min}^{-1}$. Total sulphate and chloride concentrations were corrected for porosity, which was determined according to a previously described method $^{26}$. 
$1 \quad$ W. S. Reeburgh, in Vol. 4 Treatise on Geochemistry, edited by R. F. Keeling (Elsevier-Pergamon, Oxford, 2003), pp. 65.

2 N. Iversen, in Microbiology of Atmospheric Trace Gases, edited by J. C. Murrell and D. P. Kelly (Berlin, 1995), pp. 51. K. -U. Hinrichs and A. Boetius, in Ocean Margin Systems, edited by G. Wefer, D. Billett, and D. Hebbeln (Springer-Verlag, Berlin, Berlin, 2002), pp. 457. N. Pimenov, A. Savvichev, I. Rusanov et al. Microbial processes of carbon cycle as the base of food chain of Håkon Mosby mud volcano benthic community. Geo-Marine Letters 19, 89 (1999). G. Aloisi, I. Bouloubassi, S. K. Heijs et al. CH4-consuming microorganisms and the formation of carbonate crusts at cold seeps. Earth and Planetary Science Letters 203 (1), 195 (2002). A. Stadnitskaia, G. Muyzer, B. Abbas et al. Biomarker and 16S rDNA evidence for anaerobic oxidation of methane and related carbonate precipitation in deepsea mud volcanoes of the Sorokin Trough, Black Sea. Marine Geology 217 (12), 67 (2005). H. Niemann, J. Duarte, C. Hensen et al. Microbial methane turnover at mud volcanoes of the Gulf of Cadiz. Geochimica Et Cosmochimica Acta (accepted). D. de Beer, E. Sauter, H. Niemann et al. In situ fluxes and zonation of microbial activity in surface sediments of the Hakon Mosby Mud Volcano. Limnol Oceanogr 51 (3), 1315 (2006). V. J. Orphan, K. U. Hinrichs, W. Ussler et al. Comparative analysis of methaneoxidizing archaea and sulfate- reducing bacteria in anoxic marine sediments. Appl Environ Microbiol 67 (4), 1922 (2001). K. Knittel, T. Lösekann, A. Boetius et al. Diversity and distribution of methanotrophic archaea at cold seeps. Appl Environ Microbiol 71 (1), 467 (2005). S. J. Hallam, P. R. Girguis, C. M. Preston et al. Identification of methyl coenzyme $\mathrm{M}$ reductase A (mcrA) genes associated with methane-oxidizing archaea. Appl Environ Microbiol 69 (9), 5483 (2003). P. R. Girguis, V. J. Orphan, S. J. Hallam et al. Growth and methane oxidation rates of anaerobic methanotrophic archaea in a continuous-flow bioreactor. Appl Environ Microbiol 69 (9), 5472 (2003). M. O. Schrenk, D. S. Kelley, J. R. Delaney et al. Incidence and diversity of microorganisms within the walls of an active deep-sea sulfide chimney. Appl Environ Microbiol 69 (6), 3580 (2003).

A. Boetius, K. Ravenschlag, C. Schubert et al. A marine microbial consortium apparently mediating anaerobic oxidation of methane. Nature 407, 623 (2000). V. J. Orphan, C. H. House, K. U. Hinrichs et al. Methane-consuming archaea revealed by directly coupled isotopic and phylogenetic analysis. Science 293 (5529), 484 (2001). A. A. Raghoebarsing, A. Pol, K. T. van de Pas-Schoonen et al. A microbial consortium couples anaerobic methane oxidation to denitrification. Nature 440 (7086), 918 (2006). sulfate reducers and other bacteria in sediments above gas hydrate (Cascadia margin, Oregon). Geomicrobiol J 20 (4), 269 (2003). 
M. Elvert, E. Suess, and M.J. Whiticar. Anaerobic methane oxidation associated with marine gas hydrates: superlight C-isotopes from saturated and unsaturated $\mathrm{C}_{20}$ and $\mathrm{C}_{25}$ irregular isoprenoids. Naturwissenschaften 86 (6), 295 (1999). M. Blumenberg, R. Seifert, J. Reitner et al. Membrane lipid patterns typify distinct anaerobic methanotrophic consortia. Proc Natl Acad Sci U S A 101 (30) (2004). M. Elvert, E. C. Hopmans, T. Treude et al. Spatial variatons of archaealbacterial assambladges in gas hydrate bearing sediments at a cold seep: Implications from a high resolution molecular and isotopic approach. Geobiology 3, 195 (2005). H. Niemann, M. Elvert, M. Hovland et al. Methane emission and consumption at a North Sea gas seep (Tommeliten area). Biogeosciences 2, 335 (2005). J. Taylor and R. J. Parkes. The Cellular Fatty-Acids of the Sulfate-Reducing Bacteria, Desulfobacter Sp, Desulfobulbus Sp and Desulfovibrio-Desulfuricans. Journal of General Microbiology 129 (NOV), 3303 (1983). R. J. Parkes and A. G. Calder. The Cellular Fatty-Acids of 3 Strains of Desulfobulbus, a Propionate-Utilizing Sulfate-Reducing Bacterium. FEMS Microbiol Ecol 31 (6), 361 (1985). W. Michaelis, R. Seifert, K. Nauhaus et al. Microbial reefs in the Black Sea fueled by anaerobic oxidation of methane. Science 297 (5583), 1013 (2002). M. Elvert, A. Boetius, K. Knittel et al. Characterization of specific membrane fatty acids as chemotaxonomic markers for sulfate-reducing bacteria involved in anaerobic oxidation of methane. Geomicrobiol J 20 (4), 403 (2003). T. Treude, A. Boetius, K. Knittel et al. Anaerobic oxidation of methane above gas hydrates at Hydrate Ridge, NE Pacific Ocean. Marine Ecology-Progress Series 264, 1 (2003). Wolfgang Ludwig, Oliver Strunk, Ralf Westram et al. ARB: a software environment for sequence data. Nucl. Acids Res. 32 (4), 1363 (2004). 
Fig. S-1. Phylogenetic tree showing the affiliations of HMMV 16S rRNA gene sequences to selected reference sequences of the domain Archaea. Using the ARB software package ${ }^{27}$ the tree was calculated with nearly full-length sequences by maximum-likelihood analysis in combination with filters, which consider only 50\% conserved regions of the 16 S rRNA gene of Archaea. Branching orders that were not supported by all calculation methods are shown as multifurcations. Partial sequences were subsequently inserted into the reconstructed consensus tree by parsimony criteria, without allowing changes in the overall tree topology. Clone sequences from Beggiatoa covered HMMV sediments are in boldface type.

Figure S-2. Phylogenetic tree showing the affiliations of Haakon Mosby Mud Volcano 16S rRNA gene sequences to selected sequences of the Deltaproteobacteria. The tree was calculated with nearly full-length sequences by neighbour-joining analysis in combination with filters, which consider only $50 \%$ conserved regions of the $16 \mathrm{~S}$ rRNA gene of Deltaproteobacteria. Clone sequences from HMMV sediments are in boldface type. 


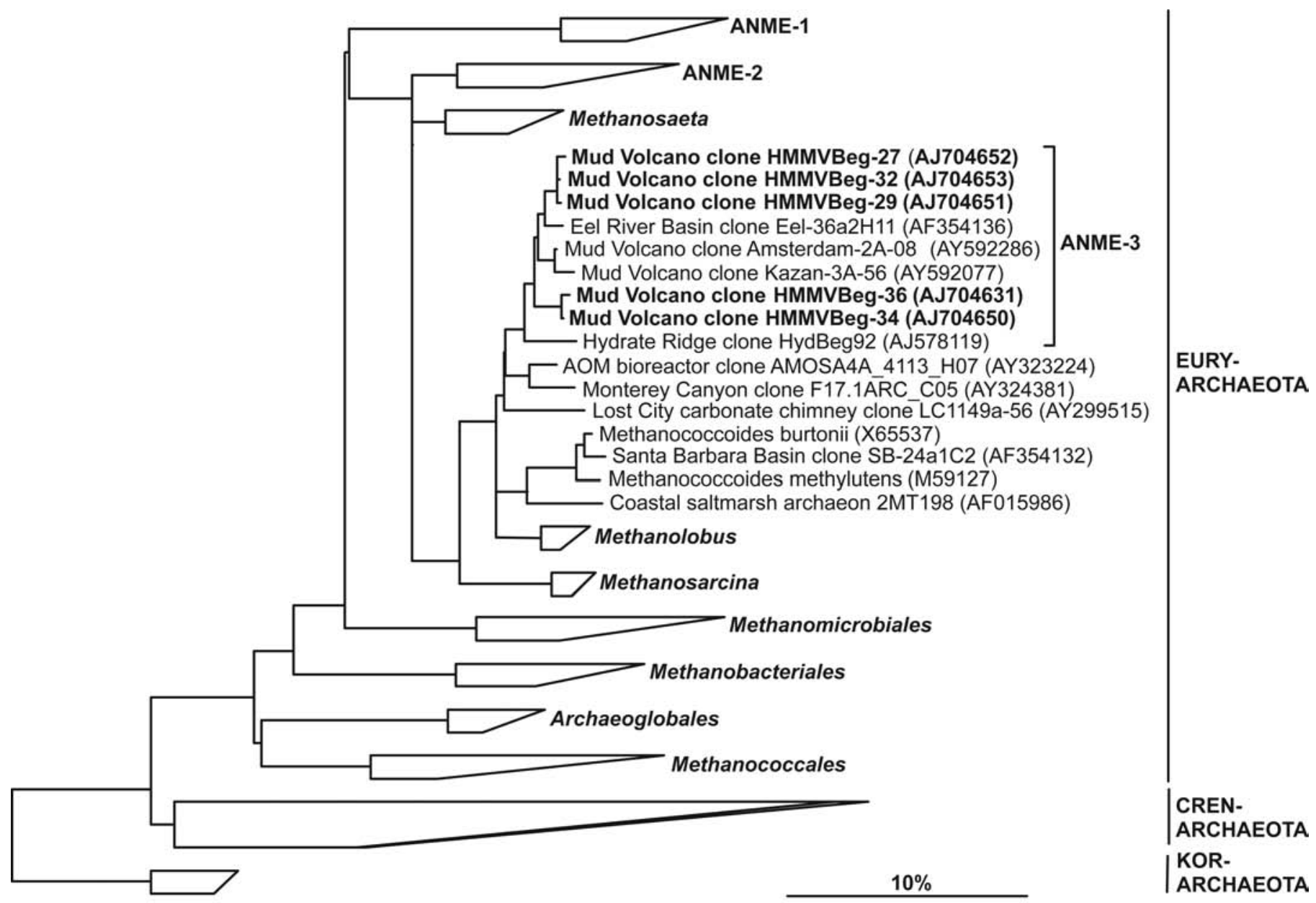




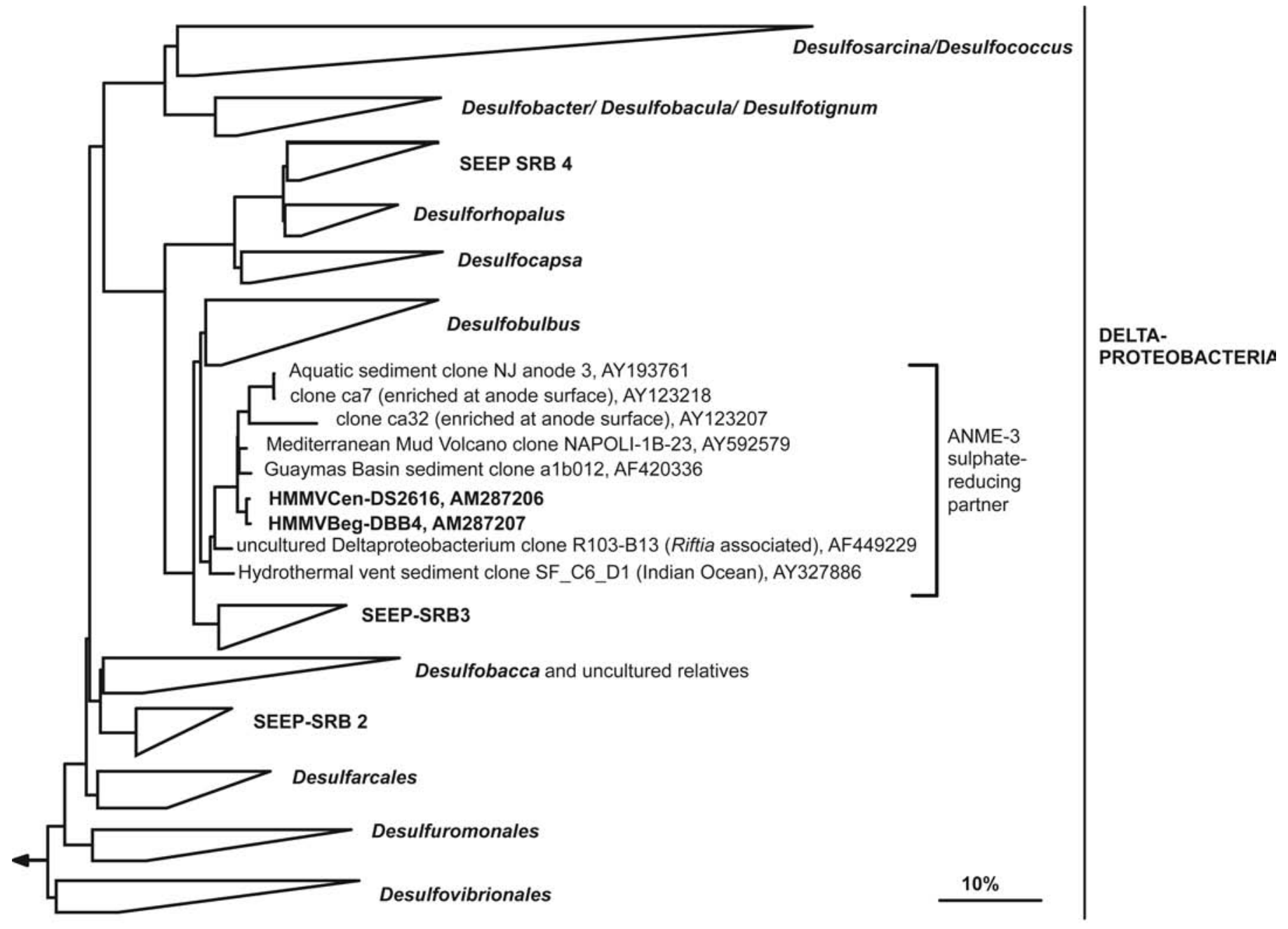

